\title{
COMMENTS
}

\section{ALASKA GIVES NINTH CIRCUIT THE COLD SHOULDER: CONFLICTS IN CAMPAIGN FINANCE JURISPRUDENCE}

\author{
ANDREW HYMAN ${ }^{\dagger}$
}

\section{INTRODUCTION}

The costs associated with mounting a full-fledged political campaign for federal, state, and local offices have increased tremendously over the past few decades.' As costs have skyrocketed, so has the need for campaign contributions to cover them. For most candidates, the preferable and most efficient way to raise campaign funds is to solicit large contributions from wealthy donors. ${ }^{2}$ The alternative would be to spend greater time and effort soliciting thousands of small contributions from a larger pool of donors. ${ }^{3}$ While the first approach is attractive, its main criticism has been the conflict of loyalties it can create for the candidate. While she is elected by the majority in her district and therefore is at least nominally answerable to her constituents, a cynical view dictates that she owes her victory to those few who funded her campaign. ${ }^{4}$ Once she is elected, this cynical view continues that

${ }^{\dagger}$ A.B. 1994, Dartmouth College; M.F.A. 1999, University of Southern California; J.D. Candidate 2004, University of Pennsylvania. I would like to thank my wife, Suzie, for her love, support, and patience throughout the writing and editing of this Comment. I would also like to thank University of Pennsylvania Law Review editors David Sontag and Danielle Estrada for their thoughtful guidance and diligence.

1 See ANTHONy CORRADO, CAMPAIGN FINANCE REFORM 28-29 \& tbl.3.1, 31 (stating that total political spending for all federal, state, and local offices increased from $\$ 425$ million to $\$ 4$ billion between 1972 and 1996 , adjusted for inflation).

${ }^{2}$ See id. at 39 ("[L]ess than one-tenth of 1 percent of the population ... contributed . . .23 percent of all the monies contributed to parties and candidates in federal elections [in 1996].").

${ }^{3}$ See id. at 34-35 (reporting that in order to be a competitive candidate, one must "develop a broad base of donors and be willing to devote substantial amounts of time to fundraising").

${ }^{4}$ Further, once the candidate is elected, commentators espousing the cynical view claim that the candidate's concern will turn to reelection. See, e.g., HERBERT E. Alexander, Financing Politics: Money, Elections, and Political Reform 7-8 
she must bestow benefits upon those wealthy few from whom she has asked, and likely will ask again, for money. This conflict of interest leads the candidate toward two potential courses of action: illegal quid pro quo corruption, where money is given in exchange for explicit, requested benefits or legislative votes, ${ }^{3}$ and legal, efficient legislation which, while facially neutral, tends to benefit the class of constituents or the industries most likely to support the legislator in her next campaign.

Late in the twentieth century, Congress saw quid pro quo corruption as a particularly dangerous practice and took steps to eliminate it from federal politics. In 1972, the Federal Election Campaign Act $(\text { FECA })^{7}$ became law, and was then substantially amended in $1974 .^{8}$ FECA and its amendments were passed primarily to remove actual and apparent quid pro quo corruption from federal elections. ${ }^{9}$ Neither it nor it regulations created state election requirements. Those had to be developed by the states.

(4th ed. 1992) (claiming that many politicians are professionals with no other assured livelihood); CoRRADo, supra note 1, at 35 (contending that federal politicians spend too much of their time raising funds for the next election to concentrate on legislating).

${ }^{5}$ See Buckley v. Valeo, 424 U.S. 1, $26-28$ (1976) (defining political corruption as real or apparent quid pro quo arrangements).

${ }^{6}$ See Spencer A. Overton, Mistaken Identity: Unveiling the Property Characteristics of Political Money, 53 VAND. L. REv. 1235, 1274-80 (2000) (describing how politicians design legislation to benefit certain donor constituents).

${ }^{7}$ Federal Election Campaign Act of 1971, Pub. L. No. 92-225, 86 Stat. 3 (1972) (current version at 2 U.S.C. $\$ \S 431-55$ and 18 U.S.C. $\$ \S 591-610(2000)$ ).

${ }^{8}$ Federal Election Campaign Act of 1974, Pub. L. No. 93-443, 88 Stat. 1263 (current version at 2 U.S.C. $\$ \S 431-55$ and 18 U.S.C. $\$ \S 591-610(2000)$ ).

${ }^{9}$ Cf. CORRADO, supra note 1 , at 38-39 (stating that an objective of FECA was to eliminate large contributions and replace them with small gifts from an increased base of constituents). Instead, political parties began to use large "soft money" donations for party-building activities and issue advocacy-often in the form of paid advertisements for candidates-to replace large direct contributions to candidates as a major source of funds for federal elections. Benjamin L. Ginsberg, "Soft Money": A Contributor's Guide, in CORPORATE POLITICAL ACTIVITIES 1990: PACs, ETHICS, AND LOBBYING LAwS, at 393, 395 (PLI Corp. Law \& Practice Course, Handbook Series No. 695, 1990) (defining "soft money" as "any contribution or expenditure affecting an election not reported pursuant to 2 U.S.C. $\$ 434 \ldots$ or not subject to the prohibitions of 2 U.S.C. $\S 441 b(a)$ or the limitations of 2 U.S.C. $\S 441 \mathrm{a})$. These soft money donations remained exempt from disclosure rules and contribution limits until recently. Bipartisan Campaign Reform Act of 2002 (BCRA), Pub. L. No. 107-171, 101, 116 Stat. 81, 82 (codified at 2 U.S.C.A. $\$ 441$ (a) (Supp. 2003)) (implementing a recent prohibition, FECA $\$ 323(\mathrm{a})$, on national committees and their agents from soliciting, receiving, or spending any soft money). 
State legislators, mindful of First Amendment protections and their own state constitutional principles, have passed a multitude of campaign finance reform laws since FECA was enacted. ${ }^{10}$ By way of these statutes, states have tried to reduce the total amount of money entering political campaigns, the amount of actual and apparent political corruption, and the effects of out-of-state and out-of-district influences over local elections, all to encourage local politicians to be more responsive to the needs of their constituents. In regard to this final tactic, at least Alaska, Oregon, Vermont, and Washington have enacted statutes designed to reduce-if not eliminate-out-of-state and/or out-of-district influence in local elections."

The line between acceptable regulation and impermissible infringement of First Amendment rights is not bright for the states. Its complexity derives from the fact that the First Amendment protects the rights of both the candidate and her supporters, but laws that infringe upon the rights of one may not infringe upon those of the other. The Supreme Court's ruling in Buckley v. Valeo ${ }^{12}$ further complicated matters by determining that certain acts, such as writing a check, though arguably pure conduct, are protected by the First Amendment as political speech. ${ }^{13}$

The United States Supreme Court has yet to directly address the constitutionality of state laws that limit participation in the political processes to residents. There have been federal circuit court and state supreme court decisions, but no constitutional consensus has been reached among them. The failure of the United States Supreme Court to grant certiorari to any of these cases has left a hole in the campaign finance jurisprudence, which has been the subject of recent litigation. This Comment explores the debate between the Ninth Circuit and the Alaska Supreme Court regarding the constitutional limits of laws that fall into this jurisprudential gap. Specifically, it examines how the two courts reached different conclusions when interpreting

${ }^{10}$ See generally Robert D. Lenhard, No Bucking Buckley: Courts Strike Down State Campaign Finance Reforms Again and Again and Again, LEGAL TIMES, Dec. 21, 1998, at 45 (listing the state campaign finance laws).

"See id. at 46 (grouping together Alaska's, Oregon's, and Washington's out-of state and out-of-district contribution restrictions); see also Landell v. Vt. Pub. Interest Research Group, No. 00-9159(L), 2002 U.S. App. LEXIS 15770 (2d Cir. Aug. 7, 2002), withdrawn 300 F.3d 129 (2d Cir. 2002) (finding unconstitutional Vermont's limit on campaign contributions from out-of-state sources).

12424 U.S. 1 (1976).

${ }^{13}$ See id. at 16 ("Some forms of communication made possible by the giving and spending of money involve speech alone, some involve conduct primarily."). 
similar statutes to limit out-of-state donors from contributing money to state elections. The Ninth Circuit, in VanNatta v. Keisling, ${ }^{14}$ held unconstitutional a law that restricted candidates for Oregon state office in their ability to receive and use funds donated by contributors who resided outside the voting district of the office sought. The Alaska Supreme Court, in State v. Alaska Civil Liberties Union, ${ }^{15}$ held constitutional a law that restricted candidates for Alaska state office in their ability to receive and use funds donated by contributors who resided outside the state. Both decisions were denied certiorari by the United States Supreme Court.

While the Alaska Supreme Court's opinion went to great lengths to declare Alaska's statute compatible with the spirit of Buckley, the Ninth Circuit remained true to the narrow letter of Buckley, swiftly striking down any of the defense's arguments that strayed from the constricted doctrine, usually with little justification given. Paradoxically, the Alaska law, which arguably infringed on First Amendment rights of both the donors and donees more so than the Oregon law, was found valid, while the Oregon law was found unconstitutional.

This outcome raises a number of constitutional issues for the United States Supreme Court. ${ }^{16}$ First, it leaves a hole in current campaign finance jurisprudence, giving no guidance to state legislatorswho may be looking to reform their campaign finance statutes-as to the constitutionality of excluding nonresidents from donating to state politics. Second, it creates a conflict between the Alaska state courts, which will follow their state supreme court decision, and the United States District Court for the District of Alaska, which will follow the Ninth Circuit decision. This can potentially lead to the kind of intrastate forum shopping that Erie Railroad $v$. Tompkins ${ }^{17}$ was supposed to eliminate. Should another plaintiff bring suit on a related matter in Alaska, the choice of forum in which she should file may very well be

14151 F.3d 1215 (9th Cir. 1998), cert. denied, 525 U.S. 1104 (1999) (enjoining the enforcement of the Oregon campaign finance measure).

${ }^{15} 978$ P.2d 597 (Alaska 1999), cert. denied, 528 U.S. 1153 (2000) (upholding the vast majority of the Alaska campaign finance bill).

${ }_{16}$ The Second Circuit case, Landell, 2002 U.S. App LEXIS 15770, at *6-7, upheld the constitutionality of legislation that restricted campaign expenditures, but enjoined, on constitutional grounds, a provision limiting candidates for state offices to receiving only twenty-five percent of their funding from non-Vermonters. Landell was decided in August 2002, but the opinion was withdrawn for further proceedings and possible amendment in October 2002. When this opinion is reissued, it will doubtless be appealed to the Supreme Court.

${ }^{17} 304$ U.S. 64 (1938). 
outcome determinative. Third, until the United States Supreme Court makes a decision on this issue, elected state courts may feel compelled, as the Alaska court arguably did, to validate statesponsored prejudice against nonresidents.

Part I of this Comment will give an introduction to the constitutional issues at stake in the campaign finance reform debates as informed by Buckley $v$. Valeo. This Part will also look at selected restrictions laid down in FECA and at how the Supreme Court has dealt with federal attempts to restrict different forms of political speech. Part II will introduce the Alaska and Oregon litigation and will discuss how each state's campaign finance statute worked in practice. It will then analyze which, and whose, First Amendment rights were potentially infringed by each law. ${ }^{18}$ Part III will delve into the courts' analyses of the cases. This Comment will conclude that each court engaged in questionable analysis, and that courts should recognize additional governmental reasons for restricting political speech besides those related to the prevention of corruption. In conclusion, the Supreme Court should address the issue of out-of-state and out-of-district participation in local politics in order to prevent situations where constitutional questions can be decided based on forum choice and to protect the rights of nonresidents with in-state and in-district interests.

\section{BUCKLEY V. VALEO AND FECA}

Although the drive to reform campaign financing began in the late nineteenth century, ${ }^{19}$ it wasn't until the late twentieth century-in the wake of the Watergate scandal-that the issue came to the fore of public consciousness. ${ }^{20}$ Congress passed FECA in $1971^{21}$ and passed amendments to it only a few years later, in 1974, largely in response to

${ }^{18}$ Oregon's Ballot Measure 6 (Measure 6) was declared unconstitutional and is no longer in force, so I will refer to it in the past tense. Alaska's Senate Bill 191 (S.B. 191) was found constitutional and is still in force, so I will refer to it in the present tense wherever appropriate. At times, however, for grammatical ease, I will refer to the Alaska statute in the past tense.

${ }^{19}$ See AlEXANDER, supra note 4 , at 24 (discussing the Civil Service Reform Act of 1883 , ch. 27, 22 Stat. 403 (1883), the first real campaign finance reform law).

${ }^{20}$ Anthony Corrado, A History of Federal Campaign Finance Law, in CAMPAIGN FINANCE REFORM 13 (Christopher Luna ed., 2001).

${ }^{21}$ Pub. L. No. 92-225, 86 Stat. 3 (1972), amended by Pub. L. No. 93-443, 88 Stat. 1263 (1974). This Act created the eight-person Federal Election Commission (FEC) and placed various restrictions on campaign contributions and election advocacyrelated expenditures. 
the Nixon administration's corrupt abuses of campaign funding. ${ }^{22}$ Two years later, in Buckley $v$. Valeo, ${ }^{29}$ the Supreme Court reviewed the then-current version of FECA, invalidating some of its provisions and upholding others. In the process, the Court created a constitutional framework with which to analyze campaign finance laws. This framework was designed to balance the core First Amendment freedoms of speech and association with the governmental interest in guarding against political corruption.

In resolving Buckley, the Supreme Court divided its analysis between campaign contributions and independent expenditures. Political contributions include the giving of "any gift, subscription, loan, advance, or deposit of money ... made by any person for the purpose of influencing any election for federal office ....", Independent expenditures include money spent to "expressly advocat[e] the election or defeat of a clearly identified candidate" by those outside of and not acting in concert with a candidate's campaign. ${ }^{25}$ The Buckley Court held that any restriction on either contributions or independent expenditures necessarily infringed upon First Amendment freedoms of speech and association. However, the Court concluded that a certain amount of infringement might be permissible. ${ }^{26}$

\section{A. The Letter of Buckley}

The Buckley Court found that campaign contributions posed a much greater threat of quid pro quo corruption than did independent expenditures. ${ }^{27}$ It also found that "[FECA's] expenditure limitations impose[d] far greater restraints on the freedom of speech and association than [did] its contribution limitations," tions on each deserve separate constitutional analyses. ${ }^{29}$ Any restrictions that infringed upon independent expenditures would need to

${ }^{22}$ See, e.g., ALEXANDER, supra note 4, at 69-70 (recounting the Nixon administration's appointment of ambassadorships to campaign contributors with questionable qualifications); Ron Schaumberg \& Timothy Kelley, Got Money?, in CAMPAIGN FINANCE REFORM, supra note 20, at 39-41 (relating the story of Richard Nixon's extortion of campaign money from the dairy industry).

${ }^{23} 424$ U.S. 1 (1976).

${ }^{24} 2$ U.S.C. $\$ 431(8)$ (A) (i) (2000).

${ }^{25} 2$ U.S.C. $\$ 431(17)(2000)$.

${ }^{26}$ See Buckley, 424 U.S. at 21-23 (rationalizing contribution ceilings).

${ }^{27}$ Id. at 47.

${ }^{28} I d$. at 44 .

${ }^{29} I d$. at $19-22,44-45$. 
"satisfy the exacting scrutiny applicable to limitations on core First Amendment rights of political expression." ${ }^{\text {s0 }}$ The Court did not find any compelling state interest in Buckley that was worthy of placing restrictions on independent expenditures by individuals and groups. ${ }^{31}$ Thus, the Court struck down FECA's proposed limitations on: (a) independent expenditures by individuals and groups; (b) candidates' personal expenditures; and (c) overall campaign expenditures. ${ }^{32}$ However, in the almost three decades since Buckley, the Court has recognized one interest compelling enough to justify a state placing limitations upon independent expenditures. In Austin $v$. Michigan State Chamber of Commerce, ${ }^{33}$ the Court validated a state's interest in avoiding the potential for the corruption created by corporate "war chests" amassed through the exchange of benefits between corporations and the state. ${ }^{34}$ This is a special variation on the interest in avoiding corruption reserved specifically for corporations. The Court found this decision palatable in part because Michigan had provided, by statute, for other means by which corporations could engage in political speech, including keeping segregated funds. ${ }^{35}$

Regarding campaign contributions, the Buckley Court applied a "rigorous" standard of review rather than the more demanding strict scrutiny. ${ }^{36}$ It reasoned that contributing money was closer to an expression of association than of speech. Because the desired expression of association could be effected by the mere "symbolic act of contributing," any increase or decrease in the amount of the contribution would not change the quality or quantity of the expression. As long as the government had a "sufficiently important interest," 38 which was

Id Id at 44-45.

31 Id. at 45 .

32 Id. at 143 .

39494 U.S. 652 (1990).

${ }^{34}$ Id. at 659 ("We therefore have recognized that 'the compelling governmental interest in preventing corruption support[s] the restriction of the influence of political war chests funneled through the corporate form." (quoting FEC v. Nat'l Conservative Political Action Comm., 470 U.S. 480, 500-01 (1985) (alteration in original))).

${ }^{35}$ Id. at 660 . This is consistent with section 610 of FECA, which allows corporations to establish segregated funds through which they can make campaign contributions to candidates. Buckley, 424 U.S. at 28 n.31. Segregated funds are set up by corporations or labor unions for the purpose of influencing elections. They are kept separate from the general treasuries of the entities and are made up solely of personal contributions by employees or managers.

${ }_{36}^{36}$ Id at 29.
${ }_{38}$ Id at 21.
${ }_{38} I d$ at 25. 
"closely drawn" not prevent the candidates from amassing enough money to carry on effective advocacy, ${ }^{40}$ the restriction would be upheld. The Court recognized only one sufficiently important interest in Buckley-protection against corruption or the appearance of corruption. ${ }^{41}$ FECA's $\$ 1000$ limit on an individual's contributions to a candidate, $\$ 5000$ limit on a political committee's contributions to a candidate, and $\$ 25,000$ limit on total contributions by an individual in a calendar year were found to be closely drawn to the interest of protecting against corruption and were therefore declared constitutional. ${ }^{42}$

\section{B. The Spirit of Buckley}

When considered in the context of the ongoing political concerns and the history of campaign finance reform, the Court's decision in Buckley recognized, if indirectly, that the American political system had lost the voting public's confidence and that something had to be done to restore it. ${ }^{43}$ To achieve that end, the Court approved congressional legislation restricting campaign contributions, even while acknowledging that it infringed upon perhaps the most cherished of constitutional guarantees: freedom of speech and association. ${ }^{44}$ The governmental interest that the Court accepted to justify this infringement was the protection against corruption or the appearance of corruption, but it required no showing that the proposed limitations were preceded by actual corruption or would prevent future corruption. ${ }^{45}$ Instead, the Court gave overwhelming deference to the scant congressional findings that limits on contributions would serve to prevent corruption. ${ }^{46}$ In fact, FECA's $\$ 1000$ limit on individual contributions

${ }^{39}$ Id.

40 Id. at 29.

${ }^{4}$ Id. at 26.

Id. at 58 .

${ }^{43}$ See id. at 27 ("Congress could legitimately conclude that avoidance of the appearance of improper influence "is also critical . . . if confidence in the system of representative Government is not to be eroded to a disastrous extent." (quoting United States Civil Serv. Comm'n v. Nat'l Ass'n of Letter Carriers, 413 U.S. 548, 565 (1973))).

44 See id. at 23 ("[T]he Act's contribution and expenditure limitations both implicate fundamental First Amendment interests . . ..").

${ }^{45}$ Of course, the fallout from Watergate demonstrated actual corruption and the Court took note of this. Id. at 27 n.28.

${ }^{46}$ See id. at 30 ("[I]f [Congress] is satisfied that some limit on contributions is necessary, a court has no scalpel to probe, whether, say, a $\$ 2,000$ ceiling might not serve as well as $\$ 1,000$." (quoting Buckley v. Valeo, 519 F.2d 821, 842 (D.C. Cir. 1975))). 
to political campaigns did very little to curb corruption, the appearance of corruption, or the strong influence that large sources of money have over national policy-which some consider to be corruption and others consider to be merely the proper workings of the political system. ${ }^{47}$ It did shift the distribution of large donations from the pockets of individual candidates to those of political parties in the form of "soft money," thus placing a greater amount of control over elections and policymaking in the hands of (potentially) unelected party bosses. The Court acknowledged that FECA was not a comprehensive plan, it was the first step to repairing the broken political system and would not complete the job on its own. ${ }^{48}$ In essence, the Court determined that the idea of campaign finance reform was possibly more important than actual reform itself. ${ }^{49}$

Of course, in hindsight, it is easy to identify where the Court's predictions were flawed. The Court did believe, to some extent, that FECA would do what Congress claimed-reduce corruption. However, the Court's acceptance of such slight evidence, showing that the limitations imposed by the Act would actually curb corruption, suggests that the apparent effect upon the election process was more important to the Court than the actual effect. The spirit of Buckley is thus one of compromise and moderate activism. The end goal of

47 Compare Martin H. Redish, Money Talks: Speech, Economic Power, ANd THE VALUES OF DEMOCRACY 143 (arguing that, without change, "the political agenda will inevitably be shaped by an estimate of the money that donors will spend to promote a particular idea" (quoting Burt Neuborne, Toward a Democracy-Centered Reading of the First Amendment, 93 Nw. U. L. REV. 1055, 1072 (1999))), with Overton, supra note 6, at 1274-77 (discussing the cycle of political entrenchment whereby incumbents seek donations from beneficiaries of helpful economic legislation).

${ }^{48}$ When Congress passed BCRA, Pub. L. No. 107-155, 116 Stat. 81 (codified in scattered sections of 2 U.S.C.A. (Supp. 2003)), it took another step toward finishing the job of lessening actual and apparent corruption in federal politics. One of the major provisions of the BCRA is new FECA $\S 323(\mathrm{a})$, which prevents the national committees of political parties from soliciting, receiving, or directing "any funds, that are not subject to the limitations, prohibitions, and reporting requirements of this Act," 2 U.S.C.A. $\$ 441 \mathrm{i}(\mathrm{a})(1)$, which is to say, soft money.

${ }^{49}$ Though the Court rejected the argument that contribution limits violated the equal protection rights of political challengers as a class, Buckley, 424 U.S. at 30-31, some have argued that FECA served only to entrench incumbents, reduce issue discussion, and silence political newcomers. See, e.g., DARRELL M. WEST, CHECKBOOK DEMOCRACY: HOW MONEY CORRUPTS POLITICAL CAMPAIGNS 167-69 (2000) (explaining why the major parties drag their feet when it comes to real reform); Bradley A. Smith, Faulty Assumptions and Undemocratic Consequences of Campaign Finance Reform, 105 YALE L.J. 1049, 1072 (1996) (arguing that incumbents, with greater name recognition, have an easier time raising small amounts from a large number of people than do newcomers). 
restoring faith in the political system took precedence over the normal constitutional constraints on the infringement of First Amendment rights by which the goal was accomplished.

\section{THE RECENT LitigATION IN AL_ASKA AND OREgon}

\section{A. Ninth Circuit: Oregon Voters Don't Measure Up}

Eighteen years after the Buckley decision, in 1994, Oregon voters approved Ballot Measure 6 (Measure 6), ${ }^{50}$ allowing political candidates to "use or direct only contributions which originate from individuals who at the time of their donation were residents of the electoral district of the public office sought by the candidate. ${ }^{51}$ Section 2 of Measure 6 provided for civil sanctions against the candidate if more than ten percent of her total funding was in violation of the voting district restriction. ${ }^{52}$ The restriction applied equally to out-of-state funding and out-of-district funding. ${ }^{53}$

In 1995, VanNatta v. Keisling ${ }^{54}$ was brought in the Federal District Court for the District of Oregon to challenge the constitutionality of Measure 6. The plaintiffs argued that the Measure violated the First and Fourteenth Amendments and the Privileges and Immunities clause of Article IV of the United States Constitution. ${ }^{55}$ Upon crossmotions for summary judgment, the district court found that Measure 6 went beyond the restrictions permitted under Buckley, was not narrowly tailored to prevent corruption, and unconstitutionally infringed upon the First Amendment rights of potential contributors. ${ }^{56}$ Finding that the unconstitutional parts of the Measure were not severable, the court invalidated the entire Measure. ${ }^{57}$ The State appealed, and in

${ }^{50}$ When Ballot Measure 6 was approved by the voters, it was codified in the State constitution as OR. CONST. art. II, \$ 22 (1994).

${ }^{51}$ OR. CONST. art. II, $\$ 22, \mathrm{cl}$. 1 (1994).

${ }^{52}$ Id. at $\$ 22$, cl. 2.

${ }^{53} I d$.

${ }^{54} 899$ F. Supp. 488 (D. Or. 1995).

${ }_{55}$ Id. at 492.

${ }_{56}^{5}$ Id. at 496-97. Though the district court applied a strict level of scrutiny (compelling interest and narrow tailoring), Buckley demands only a "rigorous" level of scrutiny, which is characterized by a sufficiently important interest and a statute that is closely drawn to effectuate that interest. Buckley, 424 U.S, at 25, 30. The Ninth Circuit applied this "rigorous" scrutiny test in its review. VanNatta v. Keisling, 151 F.3d 1215, 1220-21 (9th Cir. 1998). In practice, however, the two tests seem interchangeable based on the courts' analysis.

${ }^{57}$ VanNatta, 899 F. Supp. at 497. 
1998, a divided panel of the Ninth Circuit affirmed the lower court's ruling. ${ }^{58}$ When the State again appealed, the Supreme Court denied certiorari, seemingly settling the matter. ${ }^{59}$

\section{B. Alaska Courts Trouble}

In 1996, while VanNatta was still pending in the District Court, the Alaska legislature introduced a bill analogous to Oregon's Measure 6, in this case to exclude out-of-state money from influencing state politics. The legislature preempted a popular vote on a campaign finance reform initiative by enacting its own broad reform statute, Senate Bill 191 (S.B. 191). ${ }^{60}$ S.B. 191 was more comprehensive and less restrictive than the initiative it supplanted. ${ }^{61}$ That said, S.B. 191 still contained severe limitations, prohibitions, and time restrictions on campaign contributions; prohibitions on independent expenditures; and restrictions on the use of residual campaign assets. ${ }^{62}$ However, the provision that is most important for this Comment is the subsection of S.B. 191 that placed a hard cap on the aggregate amount of money that candidates for state offices were allowed to accept from out-of-state sources. ${ }^{63}$ Where the Oregon measure effectively limited out-ofdistrict contributions to ten percent of a candidate's total funding, the Alaska statute limited out-of-state contributions to an aggregate of $\$ 20,000$ for candidates for governor or lieutenant governor, $\$ 5000$ for candidates for state senate, and $\$ 3000$ for candidates for state representative or municipal offices. ${ }^{64}$ The statute also prohibited

58 VanNatta, 151 F.3d at 1215.

${ }^{59}$ Miller v. VanNatta, 525 U.S. 1104 (1999).

${ }^{60} 1996$ Alaska Sess. Laws ch. 48 (codified at ALASKA STAT. $\$ 15$ (Michie 2002)), amended by 2003 Alaska Sess. Laws ch. 108.

${ }^{61}$ State v. Alaska Civil Liberties Union, 978 P.2d 597, 601 (Alaska 1999) (discussing how S.B. 191 was passed shortly before an Alaskan initiative to reform campaign finance was to be voted on and how S.B. 191 "was a response to the initiative and to public concerns about actual and apparent corruption in Alaska politics").

${ }^{62}$ For example, S.B. 191 section 11 limited individuals to contributing a maximum of $\$ 100$ to any candidate or group and prohibited non-group corporations from contributing at all to a candidate or group. Section 19 prohibited the conversion of campaign funds to personal income for the candidate. Section 24 prohibited anyone but an individual or a group from making independent expenditures for or against a candidate. The bill contained numerous other restrictions and prohibitions.

${ }^{63}$ ALASKA STAT. $\$ 15.13 .072$ (e) (Michie 2002), amended by 2003 Alaska Sess Laws ch. 108 (creating a cap on the amount of contributions a candidate may receive from out-of-state residents at various levels, dependent on the office sought).

${ }^{64}$ Id. These limits have since been amended to permit donations of the full statutory amount each calendar year. 2003 Alaska Sess. Laws ch. 108. Because candidates 
candidates from accepting contributions from any groups ${ }^{65}$ either organized under the laws of another state or whose members were residents of another state at the time of the donation. ${ }^{66}$

In July 1997, the Alaska Civil Liberties Union (AkCLU) brought suit against the State in the Alaska superior court claiming that S.B. 191 violated both Article 1, Section 5 of the Alaska Constitution ${ }^{67}$ and the First Amendment of the United States Constitution as applied to the states through the Fourteenth Amendment. ${ }^{68}$ On cross-motions for summary judgment, the superior court found for AkCLU. The State appealed ${ }^{69}$ and, in 1999, the Supreme Court of Alaska reversed the superior court generally but affirmed its judgment that certain time restrictions on contributions were invalid. ${ }^{70}$ This meant that the vast majority of limitations on contributions were upheld, including the restrictions on out-of-state contributions. On appeal, the United States Supreme Court denied certiorari, ${ }^{71}$ bringing a close to the courtroom controversy and locking in place the intracircuit conflict that the Alaska Supreme Court had just created.

\section{The Conflict: The 9th $v$. the 49 th}

Oregon's Measure 6 and the out-of-state provisions of Alaska's S.B. 191 have been considered equivalents, ${ }^{72}$ though clearly they are not identical. Oregon's law was constructed around district lines, ${ }^{.73}$ whereas Alaska's was designed around state borders. ${ }^{74}$ Alaska's S.B.

may only accept contributions eighteen months before the election in which they are running, ALASKA STAT. $\$ 15.13 .074$ (c) (Michie 2002), this effectively doubled the limits on out-of-state contributions.

${ }^{65}$ ALASKA STAT. $\$ 15.13 .400(8)$ (Michie 2002) (defining “'group' to mean (A) every state and regional executive committee of a political party; and (B) any combination of two or more individuals acting jointly who organize for the principal purpose of influencing the outcome of one or more elections and who take action the major purpose of which is to influence the outcome of an election").

${ }^{66}$ ALASKA STAT. \$ 15.13.072(a) (3) (Michie 2002).

${ }^{67}$ ALASKA CONST. art. I, $\$ 5$ ("Every person may freely speak, write, and publish on all subjects, being responsible for the abuse of that right.").

${ }^{68}$ U.S. CONST. amend. XIV, $\$ 1$.

${ }^{69}$ State v. Alaska Civil Liberties Union, 978 P.2d 597, 597 (Alaska 1999).

${ }^{70}$ Id. at 633-34.

${ }^{71}$ Alaska Civil Liberties Union v. Alaska, 528 U.S. 1153 (2000).

${ }^{72}$ See, e.g., Lenhard, supra note 10 , at 45 (grouping together Alaska's, Oregon's, and Washington's out-of state and out-of-district contribution restrictions).

${ }^{73}$ OR. CONST. art II, $\$ 22, \S 3$.

${ }^{74}$ ALASKA STAT. § 15.13.072(a) (Michie 2002). 
191 was premised upon legislative findings, ${ }^{75}$ whereas Oregon's Measure 6 relied only upon a popular vote. ${ }^{76}$ Oregon's limits were based upon the percentage of money coming from out-of-district sources ${ }^{77}$ while Alaska's placed hard caps on out-of-state donations regardless of the percentage of the whole those donations made up. ${ }^{78}$ These slight differences played a role in the courts' opinions, but none was weighty enough to tip the scale. Because these laws functioned slightly differently in practice, it is informative to examine quickly the effect each had on both prospective donors and candidates before addressing the courts' analyses of them.

Both Alaska's S.B. 191 and Oregon's Measure 6 restricted, and potentially infringed upon, First Amendment rights. However, from the perspective of both the would-be donor and the would-be donee, S.B. 191 was more restrictive of the First Amendment right to freedom of association than was Measure 6. Measure 6 did not restrict the total amount of money that a candidate could receive from out-of-district sources. Rather, it limited the candidate to receiving from out-ofdistrict sources, an amount of money equal to ten percent of her total campaign funds. Consequently, if she wanted to receive more money from outside of her district, she simply needed to raise more money from sources inside her district. Meanwhile, Alaska's S.B. 191 placed a hard cap on the amount of money a candidate could solicit and receive from out-of-state funds, so that once the cap was reached, it was illegal for the candidate to solicit or receive any more money from out-of-state sources, no matter how small a percentage of her total funding the out-of-state portion comprised. ${ }^{79}$

From the point of view of a would-be contributor, Oregon's Measure 6 was more flexible than Alaska's S.B. 191 and less apt to prevent her from being able to express her association with a candidate. As an illustration consider the hypothetical plight of a would-be contributor, Calvin, who lives in California: Calvin has two grandchildren, Ollie in Oregon and Allie in Alaska, who are campaigning to be state representatives. Each of them has raised $\$ 30,000$ total for their campaigns. Each has received $\$ 3000$ of that total from out-of-state sources. Calvin

${ }^{75}$ State v. Alaska Civil Liberties Union, 978 P.2d 597, 601 (Alaska 1999); see also 1996 Alaska Sess. Laws ch. 48, $§ 1$ (listing the legislative "Findings and Purpose").

${ }^{76}$ VanNatta v. Keisling, 899 F. Supp. 488, 491 (D. Or. 1995).

7 OR. CONST. art II, $\$ 22, \S 3$ (1994).

${ }^{78}$ ALASKA STAT. $\S 15.13 .072$ (e) (Michie 2002), amended by 2003 Alaska Sess Laws ch. 108 .

${ }^{7}$ Id. 
would like to contribute $\$ 1$ to each of their campaigns for "good luck." Ollie can accept Calvin's check if he can raise another $\$ 9$ within his voting district. Allie, however, will send Calvin's check back along with a note explaining that $\$ 3000$ per calendar year is the most that Allie can accept from out-of-state sources. ${ }^{80}$ If Calvin were not a grandfather from California, but rather a nonresident business owner, nonresident landowner, or seasonal worker, he would still be in the same position. If the courts are only looking at the First Amendment rights of the potential contributors, Alaska's S.B. 191 will constrict the freedom to associate more than will Oregon's Measure 6.

It is possible that the courts are also considering the associational rights of the candidates in their opinions and projecting any constitutional harm the candidates suffer onto the would-be donors. However, applying the two laws to Ollie and Allie, this theory does not seem to explain the courts' decisions. In the scenario described above, Allie is still suffering more harm than Ollie-she cannot take advantage of her right to associate with out-of-state donors after she has accepted $\$ 3000 .^{81}$

If we change the facts slightly, the discrepancy between the hypothetical candidates' positions grows. Assume Ollie and Allie each have raised $\$ 1000$ from out-of-state sources. Each has also raised $\$ 20,000$ from in-state sources. Each then receives a check for $\$ 100$ from a California civil rights watchdog group praising her respective campaign platforms. Allie must return the check with a note explaining that she cannot accept contributions from "groups" organized under the laws of another state. ${ }^{82}$ Ollie need only return a thank you note. While both candidates can claim endorsements by the California group, only Ollie can take advantage of the right to associate with it through campaign contributions. Again, Alaska's S.B. 191 infringes more on First Amendment rights than does Oregon's Measure 6.

${ }^{80}$ Id. Notably, S.B. 191 does not contain a clause that accounts for inflation. This means that the $\$ 3000$ per calendar year limit on candidates for state representative will remain unchanged until there is a statutory amendment.

${ }^{81}$ Of course she can still engage in dialogue with these donors. She simply can't accept money from them.

${ }_{82}$ ALASKA STAT. $\$ 15.13 .072$ (a) (3) (Michie 2002). The reason for the ban on donations by out-of-state groups is to prevent the funneling of money through such groups by out-of-state individuals. Another concern is that other states' disclosure laws may not be as stringent as those of Alaska, allowing foreign PACs the freedom to not abide by Alaska laws in contributing to Alaska campaigns. See, e.g., WEST, supra note 49, at 185 (explaining how George Pataki, while running for governor of New York, registered his PAC in Virginia to take advantage of lenient finance rules). 
There is one major difference between Measure 6 and S.B. 191 that may have swayed the courts' decisions. Allie, in Alaska, is legally allowed to spend the $\$ 3000$ which she may raise from out-of-state sources. Ollie, in Oregon, is legally allowed to receive the money from out-of-district sources-he may even solicit it-but he may not "use or direct" it. ${ }^{83}$ If this was a stumbling block ${ }^{84}$ for the court, it raises the issue of whose rights are being guarded. If the Ninth Circuit, as it claims, was looking to protect the associational rights of the contributor, our hypothetical Calvin, the fact that Ollie cannot spend the money Calvin donated does not subtract from the aspects of association that accompany Calvin's symbolic act of giving. ${ }^{85}$ The Court in Buckley noted that it was the act of giving, and not the thing given, to which the associational expression attached. ${ }^{86}$

The Ninth Circuit panel rejected this argument as "only mak[ing] sense in the abstract" ${ }^{, 87}$ and cited evidence that one (plaintiff) candidate refused to accept out-of-district donations from two (plaintiff) donors based on the effects of Measure $6{ }^{88}$ The fact that a candidate rejected a donation, however, is not conclusive evidence that all candidates will reject all donations. Nor is it reasonable to read the statute as requiring rejection of the funds. In fact, the increased burden of having to track the segregated funds does not effectively force candidates to reject the funds. The burden is no greater than that

${ }^{89}$ VanNatta v. Keisling, 151 F.3d 1215, 1218 (9th Cir. 1998) (Brunetti, J,, dissenting). Though Measure 6 would have made it illegal to "use or direct" the out-of-district funds, there was no penalty written into the Measure for those candidates who did spend the money. Sanctions came into play only if the amount of money from outside the district was more than ten percent of the whole. That the candidate is not supposed to spend the money raises the question of what the disposition of the out-ofdistrict funds was supposed to be. Measure 6 did not specify what would happen to these funds. Assumedly, they would be disposed of in the manner that regular unspent campaign funds are required to be dealt with by Oregon law.

${ }^{84}$ It seems that this aspect of the Measure did play into the Court's opinion. See VanNatta, 151 F.3d at 1220 (Brunetti, J., dissenting) ("[C]ampaigns will have no incentive to accept money which they cannot legally spend.").

${ }^{85}$ One could argue that the constitutional protections afforded would-be, out-ofstate contributors by this statute are nothing more than a sham designed to meet the very lowest limits of the Buckley doctrine, while actually giving no protection. If the fact that the money donated was unusable by the candidate actually discouraged people from donating at all, arguably preventing them from exercising their right to association, then the "sham rights" argument would be much stronger.

${ }^{86}$ See Buckley v. Valeo, 424 U.S. 1, 21 (1976) (noting that the "expression rests solely on the undifferentiated, symbolic act of contributing").

${ }^{87}$ VanNatta, 151 F.3d at 1220.

${ }^{88}$ Id. at 1219. One wonders if the rejection of the donation was not a strategic decision for the purposes of passing muster under the standing doctrine. 
imposed by accounting and disclosure laws, which have already been found to be constitutional. ${ }^{89}$ Arguably, the measure lessened the candidates' motivation for soliciting out-of-district funds, and it might have reduced an out-of-district donor's desire to contribute a large amount of money to that candidate, but this is the point of Measure 6 . It did not however prevent a donor from contributing a token amount to a candidate to show her support and express her association with that candidate, and it did not prevent the candidate from accepting that donation. When compared to Alaska's prohibition on contributions, Oregon's Measure 6 infringed less harshly on First Amendment rights.

Perhaps this discussion of which law infringed more on constitutionally protected rights ignores the possibility that the courts were not looking to the amount of harm done; rather they were considering the reason for doing the harm and the manner in which it was done.

\section{THE COURTS' ANALYSES}

\section{A. The Buckley Standards}

Under the rules of constitutional scrutiny as laid out in Buckley, any restriction on contributions would have to (a) further a sufficiently important interest and (b) be closely drawn to that purpose. ${ }^{90}$ Buckley recognized the prevention of "corruption and the appearance of corruption" as the only valid governmental interest that may justify the restriction of campaign contributions. ${ }^{91}$ Since Buckley, the Supreme Court has recognized some variations and derivatives of the interest in preventing corruption. ${ }^{92}$ It has not recognized any other interest to be sufficiently important to justify infringing on First Amendment rights. ${ }^{93}$

${ }^{89}$ Buckley, 424 U.S. at $67-68,143$.

${ }^{90}$ Id. at 25.

${ }^{91}$ Id. at 33 .

${ }^{92}$ See, e.g., Austin v. Mich. State Chamber of Commerce, 494 U.S. 652, 660 (1990) (recognizing the interest in preventing the "corrosive and distorting effects of immense aggregations of wealth that are accumulated with the help of the corporate form and that have little or no correlation to the public's support" as a variation on the interest in preventing corruption).

${ }^{93}$ See id. at 658 ("[P] reventing corruption or the appearance of corruption are the only legitimate and compelling government interests thus far identified for restricting campaign finances." (quoting FEC v. Nat'l Conservative Political Action Comm., 470 U.S. $480,496-97(1985)))$. 
The Supreme Court's test for "closely drawn" turns on whether a statute "focuses precisely on the ... narrow aspect of political association where the actuality and potential for corruption have been identified while leaving persons free to engage in independent political expression, [and] to associate actively ....,94 The Buckley contribution restrictions were determined to be closely drawn because they specifically targeted large contributions-the greatest potential source of corruption-while still allowing people to contribute money and time to the campaigns of their choice.

\section{B. Corruption and Republicanism: The Ninth Circuit's Analysis}

\section{The State's Interests}

In VanNatta, the Oregon case, the plaintiffs asserted two reasons for upholding Measure 6, one being the usual prevention of corruption theory. ${ }^{96}$ They also argued what seems to be the true motivation for the Measure: protecting the integrity of the republican form of government (i.e., ensuring that those who are elected are responsive to the needs of those in their voting district). ${ }^{97}$ The Ninth Circuit, following the letter of Buckley, rejected the latter interest as insufficient to justify infringing on First Amendment rights. Judge Ferguson, writing for the majority, even posited (probably correctly) that the initiative process itself, through which Measure 6 was adopted, might violate the republican form of government. ${ }^{98}$

The majority relied on Whitmore v. Federal Election Commission ${ }^{99}$ to bolster its case against recognizing such an interest. ${ }^{100}$ In Whitmore, the California plaintiffs were denied injunctive relief to "prohibit . . . candidates from accepting out-of-state campaign contributions." claimed that such contributions violated their right to a republican form of government. ${ }^{102}$ The Ninth Circuit held that the claim had no

${ }^{94}$ Buckley, 424 U.S. at 28.

95 Id. at 28-29.

${ }^{96}$ VanNatta v. Keisling, 151 F.3d 1215, 1221 (9th Cir. 1998) (Brunetti, J., dissenting).

${ }^{97}$ Id. at $1217,1221$.

${ }^{98} I d$. at 1216.

${ }^{99}$ 68 F.3d 1212 (9th Cir. 1995).

${ }^{100}$ VanNatta, 151 F.3d at 1217.

${ }^{101}$ Id.

${ }^{102}$ Whitmore, 68 F.3d at 1216. 
support by precedent or statute and dismissed it as "frivolous."103 Though Whitmore dealt with out-of-state rather than out-of-district contributions, the VanNatta court stated that "its holding underscore[d] the lack of support for any claim based on the right to a republican form of government." ${ }^{104}$

However, the plaintiffs in VanNatta argued that the Supreme Court impliedly recognized their claim in several cases. First, they argued the decision in Austin v. Michigan State Chamber of Commerce ${ }^{105}$ supported their claim. ${ }^{106}$ In Austin, the Supreme Court upheld a Michigan law that prohibited corporations from making independent expenditures in support of or in opposition to a candidate. ${ }^{107}$ The Austin Court reasoned that because corporations benefit from stateconferred advantages that allow company coffers to grow substantially, money that corporations spend should reflect actual public support for corporations' political ideas. ${ }^{108}$ The VanNatta plaintiffs contended that vast individual political contributions should also reflect actual public support, including the opinions of the residents of the voting district. $^{109}$ The Court dispatched with this argument, reasoning that Austin was inapplicable; it dealt only with corporations and their state-conferred benefits and did not touch on the issue of in-district versus out-of-district donations. The plaintiffs were arguing political theories and the Court was only interested in the letter of judicial precedence.

This divide was more apparent in the next two cases the VanNatta ${ }^{110}$ plaintiffs used: Holt Civic Club v. City of Tuscaloosa ${ }^{111}$ and Shaw v. Reno. ${ }^{112}$ In Holt, the Supreme Court stated, "our cases have uniformly recognized that a government unit may legitimately restrict the right to participate in its political processes to those who reside within its borders." 113 Because at issue in Holt was the right to vote and not

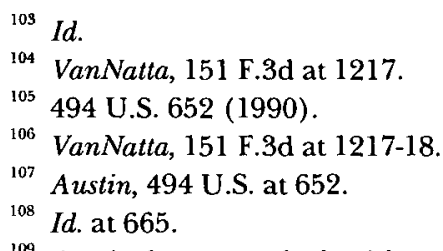

${ }^{109}$ Austin, however, dealt with a provision restricting the expenditures of corporations in support of candidates. It did not apply to contributions from individuals. See id. at 604-65 (discussing section 54(1) of the Michigan Campaign Finance Act).

${ }^{110}$ VanNatta, 151 F.3d at 1217-18.

111439 U.S. 60 (1978)

${ }^{112} 509$ U.S. 630 (1993)

${ }^{113}$ Holt, 439 U.S. at 68-69, quoted in VanNatta, 151 F.3d at 1218. 
the First Amendment right to free speech and association, the VanNatta court found that it did not support upholding Measure $6 .{ }^{114}$

In Shaw, the Supreme Court recognized that when elected officials represent one interest group rather than their entire constituency, there has been cognizable harm done under the Fourteenth Amendment:

When a district obviously is created solely to effectuate the perceived common interests of one racial group, elected officials are more likely to believe that their primary obligation is to represent only the members of that group, rather than their constituency as a whole. This is altogether antithetical to our system of representative democracy.

The VanNatta court acknowledged that this suggests that "states have a strong interest in ensuring that elected officials represent those who elect them."116 The principle derived from Shaw-that elected officials should be responsive to the needs of their constituency-seems to further the case in support of Measure 6. By eliminating the temptation to cater to the interests of out-of-district contributors, the official will concentrate on representing those who elected her. ${ }^{1{ }^{17}}$

However, in keeping with its by-the-letter readings, the court distinguished Shaw as the "inverse situation"118 of VanNatta, representative of a small group of constituents as opposed to a representative of a small group of nonconstituents. Though the VanNatta court did not expand upon its reason for rejecting the Shaw interest in ensuring proper representation, it did state that the plaintiffs had taken the case "out of context."119 This suggests that the court read the Shaw arguments as being applicable only in the context of race-based redistricting. At the end of the day, the "prevention of corruption" or the "appearance of corruption" were still the only interests sufficient to justify infringement on political speech.

\footnotetext{
114 VanNatta, 151 F.3d at 1218.

${ }^{115}$ Shaw, 509 U.S. at 648.

116 VanNatta, 151 F.3d at 1218.
}

${ }^{117}$ The argument can be made that the official will still only be responsive to those in her district who donated to her campaign. However, in Shaw the perceived problem was that no matter who was elected, the victor would feel that it was her duty only to represent the "minority" population of her district. In contrast, under Measure 6, though an official might represent only the views of her donors or members of her party, those whose views are represented will change with the election of a different official.

118 VanNalta, 151 F.3d at 1218.

${ }^{119} \mathrm{Id}$. 
Judge Brunetti, in the VanNatta dissent, diverged from Judge Ferguson's strict interpretation of case law. Judge Brunetti argued that perhaps the Supreme Court had impliedly recognized an interest in protecting the "integrity of political structures and processes." He looked at Austin, Holt, and Shaw and concluded that although none of them were exactly on point, together they suggest that "states ... have a strong interest in making sure that elections are decided by those who vote." 121

In reaching the conclusion that Measure 6 supports this interest, Judge Brunetti assumed that contributions are proxies for votes-that those who make contributions are actually deciding the election. He mentioned that there is "statistical and anecdotal evidence suggesting a strong correlation in Oregon between receiving funds and winning elections." 122 Of course, a "correlation" said nothing of cause and effect, and did not resolve the question of whether it is the ability to raise money that influences election outcomes or whether a candidate who is already favored attracts donations. ${ }^{123}$ Just as Judge Ferguson seemed to have gone out of his way to construe precedent narrowly, Judge Brunetti seemed to have gone out of his way to construe it broadly; he was much more willing than the majority to look at patterns and judicial suggestions to conclude that Oregon had a "sufficiently important interest" that justified infringing on certain wouldbe contributors' First Amendment rights. In a sense, Judge Brunetti's opinion looked much more like that of the Alaska Supreme Court. ${ }^{124}$

\section{The Close-Drawing Analysis}

The Ninth Circuit has streamlined the Buckley test for close drawing, determining that it is based on whether a piece of legislation is over- or underinclusive. ${ }^{125}$ Under this test, Oregon's Measure 6 was

${ }^{120}$ Id. at 1225 (Brunetti, J., dissenting).

${ }^{121} I d$. at 1223.

${ }^{122}$ Id. at 1219 .

${ }^{123}$ Though Judge Brunetti cites statistics that in Oregon in 1992, "[h]ouse candidates received $81 \%$ of their money from PACs and corporations, [and] senate candidates received $75 \%$ from those sources," many PACs support multiple candidates in single elections to hedge their political bets. Id.

${ }^{124}$ See discussion infra Part III.C (discussing the Alaska Supreme Court's analysis in State v. Alaska Civil Liberties Union, 978 P.2d 597 (Alaska 1999)). In fact, that opinion, regarded as the leading Alaska opinion on this issue, cites Judge Brunetti's dissenting opinion numerous times with approval. Id. at $616 \mathrm{nn}, 121-22 \& 125-26$.

${ }^{125}$ VanNatta, 151 F.3d at 1223 (Brunetti, J., dissenting) (citing Serv. Employees Int'l Union v. Fair Political Practices Comm'n, 955 F.2d 1312, 1322 (9th Cir. 1992)). 
not closely drawn to prevent corruption or the appearance of corruption.

The corruption that the Buckley Court had been concerned with was two-fold: (a) the giving of large contributions "to secure a political quid pro quo from current and potential office holders," and (b) improper influence over elected officials. ${ }^{126}$ In Federal Election Commission v. National Conservative Political Action Committee, the Supreme Court stated that improper influence occurs when "officials are influenced to act contrary to their obligations of office by the prospect of financial gain to themselves or ... their campaigns."

The Ninth Circuit found that Measure 6 was both over- and under-inclusive with respect to curbing corruption ${ }^{128}$ and therefore failed the close-drawing test. ${ }^{129}$ Judge Brunetti ${ }^{130}$ found it over-inclusive

The close-drawing test for campaign contributions comes from Buckley, 424 U.S. at 28. It does not look to see if the legislature has found the least restrictive means possible to achieve its end. Rather, it looks to see if the infringing legislation focuses precisely on the issue that the government was trying to eliminate. Id. In Buckley, the Court held that:

The Act's $\$ 1,000$ contribution limitation focuses precisely on the problem of large campaign contributions-the narrow aspect of political association where the actuality and potential for corruption have been identified-while leaving persons free to engage in independent political expression, to associate actively through volunteering their services, and to assist to a limited but nonetheless substantial extent in supporting candidates and committees with financial resources.

Id.

${ }^{126}$ Buckley, 424 U.S. at $26-27$.

${ }^{127} 470$ U.S. 480,497 (1985).

128 VanNatta, 151 F.3d at 1221.

${ }^{129}$ Before the court got to the issue of over- and under-inclusiveness, it raised the subject of vagueness. The Ninth Circuit, in its rush to void the measure, erred in interpreting a related Oregon Supreme Court case as saying that the word "individuals," as used in the measure, was "over-inclusive and must fail under the Oregon Constitution." Id. at 1217. In actuality, the Oregon Supreme Court did not decide the issue:

By its terms ... [Measure 6] prohibits candidates from using campaign contributions from individuals who reside outside the candidate's voting district.... On its face, it is unclear whether the provision prohibits the use of contributions from corporations, businesses, labor unions, and PACs and, if so, whether it restricts use of contributions only from those entities residing outside a candidate's voting district or, instead, flatly prohibits use of contributions from all such entities. We need not resolve those questions for the purposes of this case.

VanNatta v. Keisling, 931 P.2d 770, 779 (Or. 1997). What the Oregon Court declared to be over-inclusive and flawed was the Secretary of State's argument. See id. at 779 ("Assuming that [Measure 6] prohibits the use of political contributions from anyone except individual citizens residing inside a candidate's voting district, the Secretary of State's argument that the provision preempts any protections afforded by Article I, section 8 , in this context still is overinclusive, and fails."). 
because "[a]ppellants are unable to point to any evidence which demonstrates that all out-of-district contributions lead to the sort of corruption discussed in Buckley."131

Judge Brunetti also found Measure 6 to be under-inclusive for failing to prevent in-district corruption. Arguably, the measure is underinclusive in that it fails to deal with corruption from in-district sources. However, Buckley affirmed that "a 'statute is not invalid under the Constitution because it might have gone farther than it did,", 132 and restated the notion "that 'reform may take one step at a time, addressing itself to the phase of the problem which seems most acute to the legislative mind." "193 Under these principles, it certainly seems valid for Oregon to have first concentrated on eliminating out-of-district corruption before it set its sights on possible in-district corruption. In this respect, such under-inclusiveness should not have been the basis by which to invalidate Measure 6 . If the aspect of under-inclusiveness that bothered Judge Brunetti was the measure's failure "to prevent large out-of-district contributions so long as they do not exceed [ten percent] of the total, ${ }^{134}$ his concern is unfounded. By allowing a large contribution to be made, but preventing the use of the money, the Measure eliminates all reason for a donor to expect any quid pro quo. The large contributor gives the candidate nothing which she can use and thus no reason to be beholden. This prevents exactly the kind of corruption which Buckley addressed.

\section{Leveling Playing Fields: The Alaska Supreme Court's Analysis}

\section{The Governmental Interests}

The Alaska Supreme Court recognized that the United States Supreme Court, in two of its post-Buckley decisions, ${ }^{195}$ had created a "jurisprudence based on the threat of corruption and the appearance of corruption, and dependent on case-specific analysis." ${ }^{\text {196 }}$ In Buckley, the

${ }^{130}$ This section of Brunetti's opinion was adopted as the majority opinion. VanNatta, 151 F.3d at 1216.

${ }^{131}$ Id. at 1221.

${ }^{132}$ Buckley v. Valeo, 424 U.S. 1, 105 (1976) (quoting Roschen v. Ward, 279 U.S. 337, 339 (1929)).

${ }^{193}$ Id. at 105 (quoting Williamson v. Lee Optical Co., 348 U.S. 483, 489 (1955)).

194 VanNatta, 151 F.3d at 1221.

${ }^{135}$ Austin v. Mich. State Chamber of Commerce, 494 U.S. 652 (1990); FEC v. Mass. Citizens For Life, Inc., 479 U.S. 238 (1986).

${ }^{196}$ State v. Alaska Givil Liberties Union, 978 P.2d 597, 606 (Alaska 1999). 
Supreme Court upheld legislation aimed at combating corruption and the appearance of corruption resulting from "large individual financial contributions." ${ }^{137}$ Most recently, the Court has upheld the constitutionality of laws designed to prevent corruption and the appearance of corruption caused by the circumvention of FECA restrictions in the form of soft money. ${ }^{138}$ However, when it came to justifying the restriction on out-of-state contributions, the Alaska Supreme Court accepted one rationale which the United States Supreme Court explicitly rejected. ${ }^{139}$ The Alaska Supreme Court stated:

$[\mathrm{N}]$ onresident contributions may be individually modest, but can cumulatively overwhelm Alaskans' political contributions. Without restraints, Alaska's elected officials can be subjected to purchased or coerced influence which is grossly disproportionate to the support nonresidents' views have among the Alaska electorate, Alaska's contributors, and those most intimately affected by elections, Alaska residents. These restraints therefore limit the "potential for distortion." We hold that this is a sufficiently compelling state interest. ${ }^{140}$

The "potential for distortion" referred to by the Alaska Supreme Court comes from the Supreme Court's holding in Austin. ${ }^{141}$ This particular concern that Alaskans' contributions are diminished in importance relative to the money which flows from out-of-state sources is not the equivalent of the Austin concern over corporate corruption; ${ }^{142}$ it is

${ }^{137}$ Buckley, 424 U.S. at 26.

${ }^{198}$ McConnell v. FEC, 124 S. Ct. 619, 661 (2003).

${ }^{139}$ The Alaska opinion actually mentioned with approval three interests of the state: (a) ensuring the integrity of political structures and processes; (b) preventing nonresident contributors from drowning out the voices of Alaska residents; and (c) preventing "distortion" of public opinion. Alaska Civil Liberties Union, 978 P.2d at 61617 (quoting VanNatta, 151 F.3d 1217). Because reason (c) is the only one mentioned in the "holding" paragraph, that is the one I have selected to deal with as the court's recognized interest.

${ }_{140}$ Id. at 617.

${ }^{141}$ Austin v. Mich. State Chamber of Commerce, 494 U.S. 652, 661 (1990) (discussing a Michigan statute that restricted corporations in their ability to make independent expenditures). If, as in Austin, the threat perceived by the Alaska legislature was coming from corporate entities, the reliance upon the Austin holding to justify the limit on out-of-state contributions is still misplaced. S.B. 191 already prohibited corporations from making any contributions, ALASKA STAT. $\$ 13.15 .074$ ( $\mathrm{f}$ (Michie 2002), or independent expenditures, ALASKA STAT. $\$ 13.15 .135$ (a) (Michie 2002), whether they were in-state, or out-of-state corporations. Out-of-state groups likewise were banned from making any contributions. ALASKA STAT. $\S 13.15 .072(\mathrm{a})$ (3) (Michie 2002). The additional out-of-state limits therefore only applied to individuals. Austin did not address limitations on individuals, nor did it address limitations on out-of-state donors.

${ }^{142}$ Even assuming that "distortion" is a separate interest from corruption, S.B. 191 in no way addresses the same concerns as Austin did. Under S.B. 191, contributions go 
an argument for leveling the playing field. ${ }^{143}$ Inextricably tied to the reasoning in Austin is the fact that all corporations are creatures of state law and have the potential to benefit greatly from and amass enormous amounts of money from favorable laws, which, in turn, are written by legislators who might be bought by these corporations. ${ }^{144}$ The Supreme Court emphasized that the statute at issue in Austin did "not attempt 'to equalize the relative influence of speakers on elections," "145 and that "the unique state-conferred corporate structure ... facilitates the amassing of large treasuries [which] warrant[] the limit on independent expenditures. Corporate wealth can unfairly influence elections when it is deployed in the form of independent expenditures, just as it can when it assumes the guise of political contributions." 146

In contrast to Austin, the state of Alaska, as defendant, argued that the purpose of its restriction was to "prevent nonresidents from dominating the [election] process." 147 It claimed this interest, in fact, after the United States Supreme Court had indirectly rejected it in Buckley when it said that "the concept that government may restrict the speech of some elements of our society in order to enhance the relative voice of others is wholly foreign to the First Amendment . . ."148

to the candidate and then the candidate decides how the money is spent, and the candidate is responsible for the message sent to the voters and for any backlash that may come from negative campaigning. The situation in Austin was one in which statebenefited corporations were disseminating political messages.

${ }^{149}$ A limit upon the amount of money wealthy donors may contribute to a campaign reduces the ability of those donors to garner special attention from the candidate, thus leveling the field upon which donors play. See generally Kathleen M. Sullivan, Political Money and Freedom of Speech, 30 U.C. DAvIS L. REV. 663, 678-83 (1997) (contending that all arguments for contribution limits are really arguments for leveling the playing field). Reformers believe that "leveling the playing field" is a necessary part of a campaign finance system that will better reflect the "one person/one vote" principle. Marty Jezer et al., Focus On: Restoring Faith In Government: A Proposal For Democratically Financed Congressional Elections, 11 YALE L. \& POL'Y REV. 333, 338 (1993).

${ }^{144}$ Austin, 494 U.S. at 669 . This creates a cycle that promotes corruption. See Overton, supra note 6 and accompanying text (discussing the cycle of entrenchment).

${ }^{145}$ Austin, 494 U.S. at 660 (quoting Justice Kennedy's dissent, 494 U.S. at 705).

${ }^{146} I d$. Interestingly, the Court recognized in Austin that independent expenditures could have the same corrupting effect that contributions can have, blurring the clear division it made in the Buckley framework. In Buckley, the Court proclaimed that " $[t]$ he absence of prearrangement and coordination of an expenditure with the candidate ... not only undermines the value of the expenditure ... but also alleviates the danger that expenditures will be given as a quid pro quo for improper commitments from the candidate." Buckley v. Valeo, 424 U.S. 1, 47 (1976).

${ }^{147}$ State v. Alaska Civil Liberties Union, 978 P.2d 597, 615 (Alaska 1999).

${ }^{148}$ Buckley, 424 U.S. at $48-49$. 
Furthermore, the Ninth Circuit had quoted this statement from Buckley with approval in its decision in Whitmore v. Federal Election Commis$\operatorname{sion}^{149}$ to reject the plaintiff's request for an injunction to prevent outof-state donors from giving to the campaigns of plaintiff's competitors. Yet, the Alaska Supreme Court determined that this was a constitutionally sufficient interest.

The Alaska Supreme Court did this by first positing the interest as a slight variation on the Austin interest, presenting it to the world in the only acceptable light-as a tool against corruption. ${ }^{150}$ When Austin itself is examined, however, the two interests could not be more different. Then, in distinguishing itself from VanNatta, the court adopted an extremely narrow reading of the Ninth Circuit's decision. The court rationalized that “Oregon's out-of-district restrictions applied to both nonresidents and residents of Oregon. Alaska's challenged provisions, however, apply only to nonresidents of Alaska. . . Also, Alaska is not contiguous to any other state. ..."151

Finally, and most importantly, the court seemed to want to find this section of the statute constitutional. It embraced, what can be seen as, the activist spirit of Buckley. The court knew that this was a popular cause, ${ }^{152}$ as it had gotten enough popular support to become a ballot initiative. ${ }^{153}$ There was ample evidence provided by the State, through newspaper articles and opinion polls, that voters worried

${ }^{149}$ Whitmore v. FEC, 68 F.3d 1212, 1216 (9th Cir. 1996).

${ }^{150}$ The State, as the defendant in this case, argued that the sufficiently important reason for the contribution limits on out-of-state donors was to "'prevent nonresidents from dominating the process,' and that 'by restricting the influence of nonresidents ... the reforms promote the valid state goal of encouraging voter participation in campaigns ...." Alaska Civil Liberties Union, 978 P.2d at 615 (quoting the State's position). The court concluded that neither of these was a valid interest, $i d$., and instead declared the interest to be Austin's "potential for distortion," which the Supreme Court had noted as a type of corruption. Id. at 617 (quoting Austin, 494 U.S. at 661).

${ }^{151}$ Id. at 616 (Alaska 1999).

${ }^{152}$ See Brennan Ctr. for Justice, N.Y.U. Sch. Of LaW, Writing Reform: A Guide to DRAFTing STATE \& Local Campaign Finance Laws II-4 (Goldberg ed., rev. ed. 2001) (recognizing that statutes aimed at leveling the playing field tend to be popular statutes and suggesting that drafters disguise this egalitarian purpose behind an anticorruption rationale in order to get past Buckley), available at $\mathrm{http}: / / \mathrm{www}$. brennancenter.org/resources/books.html\#cfr.

${ }^{159}$ See Campaign Finance Reform Initiative, Q. NEwSL. (Alaskan Pub. Int. Res. Group, Anchorage, Alaska), Spring 1996, at 1 (discussing the "overwhelmingly successful initiative petition drive to put campaign finance reform on the November 1996 ballot [that] awakened the long slumbering Alaskan Legislature," and the Alaskan Public Interest Resource Group's (AkPIRG) role in that ballot initiative), available at http:// www.akpirg.org/publications/newsletters/newsletterspring96.pdf. The "awakening" in the Alaskan legislature to which AkPIRG referred was S.B. 191. 
greatly about corruption and had little fear of the potential discrimination against nonresidents. ${ }^{154}$ The court's understanding of the populace led to its explanation:

Alaska has a long history of both support from and exploitation by nonresident interests. Its beauty and resources have long been lightning rods for social, developmental, and environmental interests. More than 100 years of experience, stemming from days when Alaska was only a district and later a territory without an elected governor or voting representation in Congress, have inculcated deep suspicions of the motives and wisdom of those who, from outside its borders, wish to remold Alaska and its internal policies for dealing with social or resource issues. Outside influence plays a legitimate part in Alaska politics, but it is not one that Alaskans embrace without reservation.

Thus, regardless of whether the statute was meant to prevent corruption, ${ }^{156}$ its passage alone served to lessen the appearance of corruption and restore confidence in the Alaskan political system. It also served as an assertion of Alaska's independence and drive for selfdetermination. This, it seems, was the true "sufficiently important interest."

\section{But Is It Closely Drawn?}

Once the Alaska Supreme Court decided to accept "preventing nonresident contributors from drowning out the voices of Alaska residents" ${ }^{157}$ as a constitutionally permissible interest, ${ }^{158}$ the court was home-free. It could not have found a way to more narrowly tailor such an interest than placing a restriction on the ability of nonresident individuals and groups to contribute money to Alaska campaigns. This prevented the specific apparent evil while leaving out-of-state individuals and groups free to engage in independent political activities.

The Alaska Supreme Court did not probe any further to determine whether the statute was over- or under-inclusive. Though

${ }^{154}$ Alaska Civil Liberties Union, 978 P.2d at 620.

${ }^{155}$ Id. at 617.

${ }^{156}$ See id. ("We therefore conclude the record contains no evidence relating to the potential impact of [the] provision [restricting contributions by nonresident groups].").

${ }^{157} I d$.

${ }^{158}$ Although the court acknowledged that "[o] utside influence plays a legitimate part in Alaska politics," id., the court went on to hold that the concern that "Alaska's elected officials can be subjected to purchased or coerced influence which is grossly disproportionate to the support nonresidents' views have among the Alaska electorate ... is a sufficiently compelling state interest." Id. 
evidence was presented that supported the need to prevent corruption in Alaska politics, there was no evidence that identified out-ofstate contributors as a source of the corruption. ${ }^{159}$ In fact, the court went so far as to say that " $[t]$ he State refers us to no specific evidence of corruption or the appearance of corruption caused by out-of-state contributions, and does not contend that quid pro quo corruption justifies these restraints." 160 The court did point to two affidavits which claim that out-of-state donations create conflicts of loyalty for politicians. ${ }^{161}$ Former Governor Walter Hickel stated in his affidavit that "whenever a candidate has to seek donations from outside the state, the candidate is buying a potential conflict of interest." 162 The court quotes a similar statement from former Governor Jay Hammond, which concentrated on the appearance of corruption created by outof-state contributions. ${ }^{163}$ However, no argument is ever made as to why money from out-of-state contributors creates greater conflicts, or is a greater source of evil, than money that comes from sources within the state.

Additionally, it would be extremely simple-minded to think that all Alaskans speak with one voice or that the interests of Alaskans are necessarily different from the interests of other Americans. For instance, on the issue of oil drilling, some Texas oil companies may have interests in common with Alaskan drilling companies. Also, some Alaskan environmental groups may share interests with groups from around the country. It makes little sense to argue that policy decisions that support the drilling company are valid but those that support the oil company are corrupt-the two go hand-in-glove. With scant evidence to support the claim that out-of-state donors were a source of corruption, under Buckley, S.B. 191 should not have been held to be closely drawn.

\section{CONCLUSION}

First, both the dissent in VanNatta and the majority in Alaska Civil Liberties Union illustrate a desire of courts to recognize additional

${ }^{159}$ Id. at 615 (referring to "general evidence of the influence of money and political system corruption and appearance of corruption").

${ }_{160} I d$. This reinforces the notion that, although the court treated the governmental interest as a derivative of preventing corruption, the true purpose was "leveling the playing field."

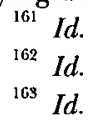


governmental interests as sufficiently important to justify contribution and other limits. Some of the interests mentioned in the two cases were derivatives of preventing corruption; but others, like leveling the playing field, were more egalitarian-minded. It is sometimes difficult to determine where the boundaries are among the interests because they tend to intersect and blend into each other. Alaska's interest seems to have been at the crossroads of leveling the playing field, protecting the republican form of government and preventing corruption. There was enough evidence, based on the protectionist stance taken by the court, to conclude that preventing corruption was the smallest part of the combined interest.

It was, of course, this protectionist position that led the court to uphold the statute. It may even be a fair assessment of the court's dicta to say that protectionism was the true interest, even more so than leveling the playing field. While protectionism may masquerade under the guise of other state interests, it is clear that states have many diverse reasons for wanting to limit contributions and expenses in political campaigns. The United States Supreme Court should recognize, as the dissent in VanNatta argued and as the Alaska Supreme Court upheld, that reasons other than the prevention of corruption exist to justify placing limits on campaign financing. These governmental interests, however, should not be used to discriminate against those persons who are not residents of the voting district of the office up for election. As argued earlier in this Comment, absent property owners, seasonal and migrant laborers, perhaps historic and environmental conservationists and others have legitimate interests in the policies and laws of the districts where they work, in which they own property, where they pay taxes, and where they enjoy significant natural and historical resources, even if they are not residents of those districts. Because they cannot vote, they must be allowed to participate in the political process to the extent that residents are in order to protect their interests.

Second, if it is correct that the outcome of Alaska Civil Liberties Union was dependent upon the forum in which it was brought, then the suit is valuable only as a lesson in litigation strategy, rather than as one of constitutional law. Now that the case has been decided, the choice of forum will be outcome determinative should any other suit call into question the constitutionality of campaign finance legislation that limits the rights of nonresidents to participate in the political process. The Alaska state courts will have to follow the precedents set by the Alaska Supreme Court in Alaska Civil Liberties Union and the United 
States District Court for the District of Alaska will have to follow precedents set by the Ninth Circuit in VanNatta.

It is troubling that questions of constitutional guarantees should be decided based upon forum choice. In order to correct this potential problem of intrastate forum shopping, the United States Supreme Court should not again deny certiorari for a similar case and the Court should rule decisively upon the constitutionality of limiting the ability of nonresidents to participate substantially in state and local politics. The behavior of the Alaska Supreme Court-which took so many activist steps to help S.B. 191 survive, from loose interpretations of precedent to unusually narrow readings of statutory provisions, even going so far as to invoke the history of exploitation of state resources by out-of-state interests-might be a sign of what is to come in future state campaign finance reform litigation.

In Oregon, the state senate has considered a plan to amend the freedom of speech guarantees in the state constitution, which have been interpreted more broadly than the First Amendment to the United States Constitution, in order to allow for legislation placing limits on campaign contributions. ${ }^{164}$ While the fate of this initiative is uncertain, it would not be surprising if Oregon, in this effort or a future one, attempts to adapt the Alaska model of nonresident discrimination for its own purposes when the state legislature eventually proposes its own campaign contribution restrictions.

If Alaska becomes the popular model for states to follow in future state campaign finance legislation, that could lead to a substantial problem of state discrimination against nonresidents. Because nonresidents cannot vote, bias and prejudice against them, in terms of limiting their ability to influence politics, carry very little in the way of political repercussions for candidates-outside of losing their campaign funding. When discrimination against nonresidents becomes popular among voters, whether grounded in reason or not, it is politically exigent for representatives and elected courts to bend to the will of the voting population. This has the potential to limit and destroy the in-state interests of nonresidents and may potentially impact our federal form of government by encouraging people to concentrate their interests where they can protect them.

Lest you think that discrimination against out-of-state donors is an issue limited to states with small populations, it is worth mentioning

${ }^{164}$ Peter Wong, Lawmakers Seek Contribution Caps, Statesman J. (Salem, Or.), Mar. 5,2003 , at $2 \mathrm{C}$. 
that Congressman Peter Hoekstra, Republican from the Second Congressional District of Michigan, has proposed a bill in the United States House of Representatives that would limit United States Congresspersons to receiving from out-of-state individuals at most twentyfive percent of the campaign funding that they receive from all individuals. ${ }^{165}$ Without a showing that out-of-state donors pose a greater risk of corrupting legislators than the in-state donors do, it is unnecessary and prejudicial to draft laws that place greater restrictions upon the First Amendment rights of the out-of-state donors.

In conclusion, if a state is satisfied that a certain contribution cap will prevent residents from entering into corrupt agreements with candidates, that cap should likewise be sufficient to prevent out-ofstate contributors from garnering special favors from the candidates. Unless and until the United States Supreme Court accepts a case dealing with these issues, and creates a concrete standard for the treatment of out-of-state donors, states will continue to discriminate against, and infringe upon, the First Amendment rights of such donors in ways that are perhaps more politically exigent than democratically necessary.

${ }^{165}$ See Accountability and Transparency in Federal Campaigns Act of 2003, H.R. 2529, 108th Cong. $\$ 3(\mathrm{a})$ (2003) (proposing to amend BCRA, 2 U.S.C.A. 44la $§ \mathrm{k}(1)$ (Supp. 2003), to require that, of the money from individuals received by candidates for the offices of United States Senate or House of Representatives, seventy-five percent must come from in-state individuals). 